\title{
INFLUENTIAL DETERMINANTS OF INNOVATION: CASE STUDY OF LATVIA AND GERMANY
}

\author{
Carolin Kuhn ${ }^{1}$, Ilona Dubra ${ }^{2}$, Erika Sumilo ${ }^{3}$ \\ University of Latvia (Latvia)
}

\begin{abstract}
Innovation is often recognized as a vital source of competitive advantage for business. Taking into account the conditions of increasing globalization at a high level of intensity as well as a rapidly changing technological landscape and also continuous customer demands for new products and services on the modern market, it is needed to assume that businesses have to innovate in order to survive and prosper in the contemporary environment. In the context of the paper at hand the main attention is given to the analysis of the theoretical and empirical aspects of the concept of innovation. There were applied such economic science research methods as monographic, grouping, reference, generalization, graphical analysis and content analysis.
\end{abstract}

KEY WORDS: innovation, growth, Germany, Latvia, competitiveness, enterprise.

JEL CODES: A11; A12; A13; H52; M21; O16; O31; O32; O34; O38; O52

\section{Introduction}

Unfortunately, there is a lack of innovative entrepreneurial activity in the context of the Latvian economic sector. According to Eurostat latest data, Latvia counts with the poorest ratio of the innovative enterprises and this fact may result in low business environment at all and for sure in dramatic threats and hard national economic sector stroke. Taking into account Germany's successful innovation policy and state leader positions in the sphere of innovation, it is useful to organize a deep research of German enterprises innovation experience in order to bring to light influential determinants on innovation creation and, in consequence, to apply these factors and make use of the research in order to foster innovative activities in Latvian enterprises. The object of the paper is the influencing factors of enterprise innovation in Germany and in Latvia. The purpose of this paper therefore is to determine these in general and then to compare the specific situation in Germany and Latvia.

The main tasks of the paper are stated as follows:

- to investigate the key theoretical aspects of the concept of innovation;

- to provide a review of the empirical findings of factors impacting on innovation;

- to examine innovation determinants in Germany;

- to examine innovation determinants in Latvia.

1 Carolin Kuhn - University of Latvia, Economics and management faculty, PhD student, Dipl.-Wirt.-Ing. Scientistic interests: Organizational culture, organization theory, innovation management, marketing.

E-mail: carolinkuhn@web.de

Tel.: +49 1778747249.

2 Ilona Dubra - University of Latvia, Economics and management faculty, PhD student, Mg. oec. Scientistic interests: human capital, organizational culture university industry linkages, innovation economics.

E-mail: ilona.dubra@inbox.lv

Tel.: +371 26407972

3 Erika Sumilo - University of Latvia, Economics and management faculty, Dr. oec. Prof. Scientistic interests: Human development, economic history, international economics, international business, cross-cultural business relations.

E-mail: sumilo@1u.lv 
In the context of the paper there were applied such economic science research methods as monographic, grouping, reference, generalization, graphical analysis and content analysis. In the first part, the paper reveals the wide range of a definition of innovation and why it is so important. Secondly, it stresses out the importance of an analysis of key factors that may have a high impact on the creation of enterprise innovation in general. In this section many different internal and external drivers for innovations in industrial organizations are explained based on a deep literature research. In the final two parts, this paper reveals the very different situations about innovation in Germany and Latvia. Whereas more than 2/3 of annual funding invested in research in Germany comes from the private sector and these funds are spent on the companies' own research as well as on joint projects with partners from science, there is not any appropriate national innovation system in Latvia. Total government budget appropriations or outlays on R\&D and expenditures on R\&D as a per cent of GDP in Latvia stand at a dramatically low level. There is a lack of scientists in entrepreneurial activities in Latvia. Besides, there is a systematic lack of support actions and financial support for innovation development in Latvia. In Germany, on the other hand, the high standard of technical expertise is the most important driver for innovation. To sum up, this paper helps to get a deeper understanding of the differences between the two countries investigated. However, it is designed be an inspiration of how to improve innovation power for both countries and finally, of course, suggests further research on the topic of innovation.

\section{Innovation - what it is and why it matters}

In many terms innovation is a very commonly used word today. You can find it in the news on TV, in the papers, or even on the radio, quite regularly. However, it is not always clear what this term really means. This certainly needs clarification, because not every new idea or product is naturally an innovation. On the contrary, out of 100 ideas only 13 make it to a fully developed product that is launched on the market and only 6 actually become a product success here as 0 shows.

"One of the problems in innovation is the variation in what people understand by the term, often confusing it with invention" (Tidd, Bessant, 2009: 16). The word innovation originates in the Latin vocabulary "innovare" - to make something new (Langenscheidt, 2001: 653). Invention on the other hand goes back to "invenire", also Latin - to discover something (Langenscheidt, 2001: 684). Still, this does not clearly explain the difference between the two. As Thomas A. Edison (1847-1931), the US-American inventor of the light bulb, once put it: "Anything that won't sell, I don't want to invent. Its sale is proof of utility, and utility is success" (Tidd, Bessant, 2009: 20). Only a successfully marketed invention can be defined as an innovation. It has to be successful on the market and money must be gained from it. Innovation is the "process of turning opportunity into new ideas and of putting these into widely used practice" (Tidd, Bessant, 2009: 16). There-

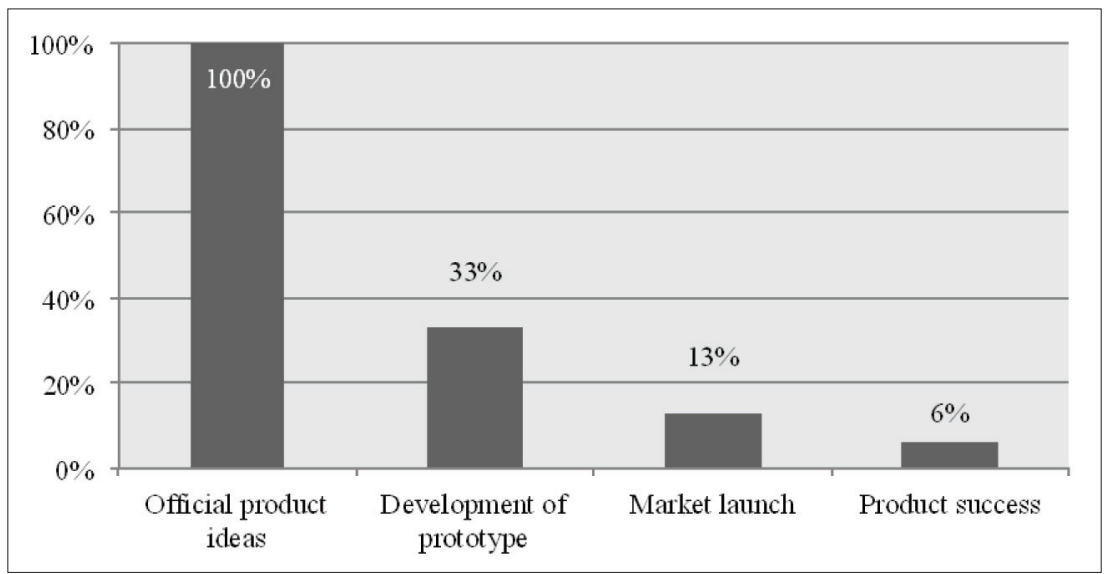

Figure 1. Percentage of ideas becoming a product success

Source: Kerka \&Kriegesmann, 2010: 3 
fore, for profit-oriented organizations it is innovation, not only invention that helps them to gain economic growth. Being a good inventor is never a guarantee of commercial success (Tidd, Bessant, 2009: 17). However, innovation is not only about products. It may also be found in the means for creating or delivering it (Amabile, 1996: 3) and basically describes the implantation of creative ideas within an organization.

Innovation is a fundamental element of long-term success (Davila et al., 2006: 16). Today, it matters not only at the level of the individual enterprise but also increasingly as the origin for national economic growth (Tidd, Bessant, 2009: 5). There are enough analyses that prove a mutual dependency between innovation and success of companies. Statistics Canada for example identified in 2006 that innovation is consistently found to be the most important characteristic associated with success in companies. Besides, innovative enterprises typically achieve stronger growth or are more successful than those that do not innovate (Statistics Canada, 2006). In fact, innovation has become a core driver of growth, performance, and valuation (Barsh et al., 2008: 37).

$70 \%$ of organizations with a positive attitude towards innovation declare that they outperform their competitors and it is those companies that have seen an increase in profits over the past years (Von Stamm, 2008: 480). Furthermore, you can find analyses revealing that there is a clear connection between the technological position of a business area, its market position, its earnings and the extent to which it can safeguard jobs and even expand its workforce (Eberl, Puma, 2007: 15). Therefore, it goes without doubt that the ability to continuously innovate is of critical importance to the long-term success of any organization (Terziovski, 2007: 19). The need to innovate in order to keep competitive advantages is already known to be crucial for sustainable success in many companies. In the future, the only reliable security for any company is the ability to innovate better and longer than competitors. And, "organizations (...) cannot expect to survive without innovation" (Davila et al., 2006: 28).

\section{External and internal drivers for innovation power of industrial companies}

Depending on the industries, of course, there are a number of different sources where innovative ideas can come from. In general, companies need to be able to see connections, to spot opportunities and to take advantage of them (Tidd, Bessant, 2009: 3). Nevertheless, customers, competitors, partners, and even new governmental or environmental regulations can bring inspiration. New regulations or users who become innovators can be as much of an inspiration and therefore the beginning of an innovation as a knowledge push in the research and development department or as challenging competition. A 2010 research for Wirtschaftswoche found that companies themselves admit getting their best ideas for innovation up to $40 \%$ from their customers as 0 shows. According to this, the internal innovation management plays only a minor role (13\%).

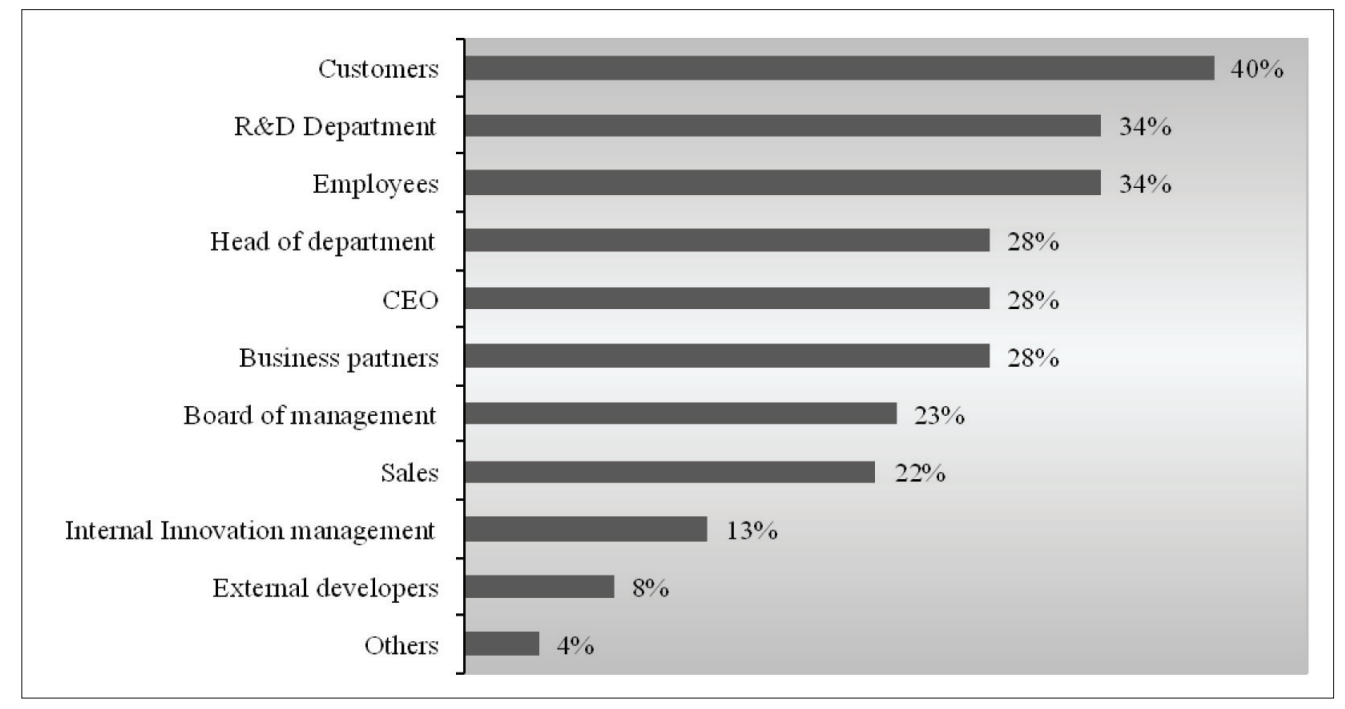

Figure 2. Where companies get their best ideas from

Source: Engeser, 2010: 96 


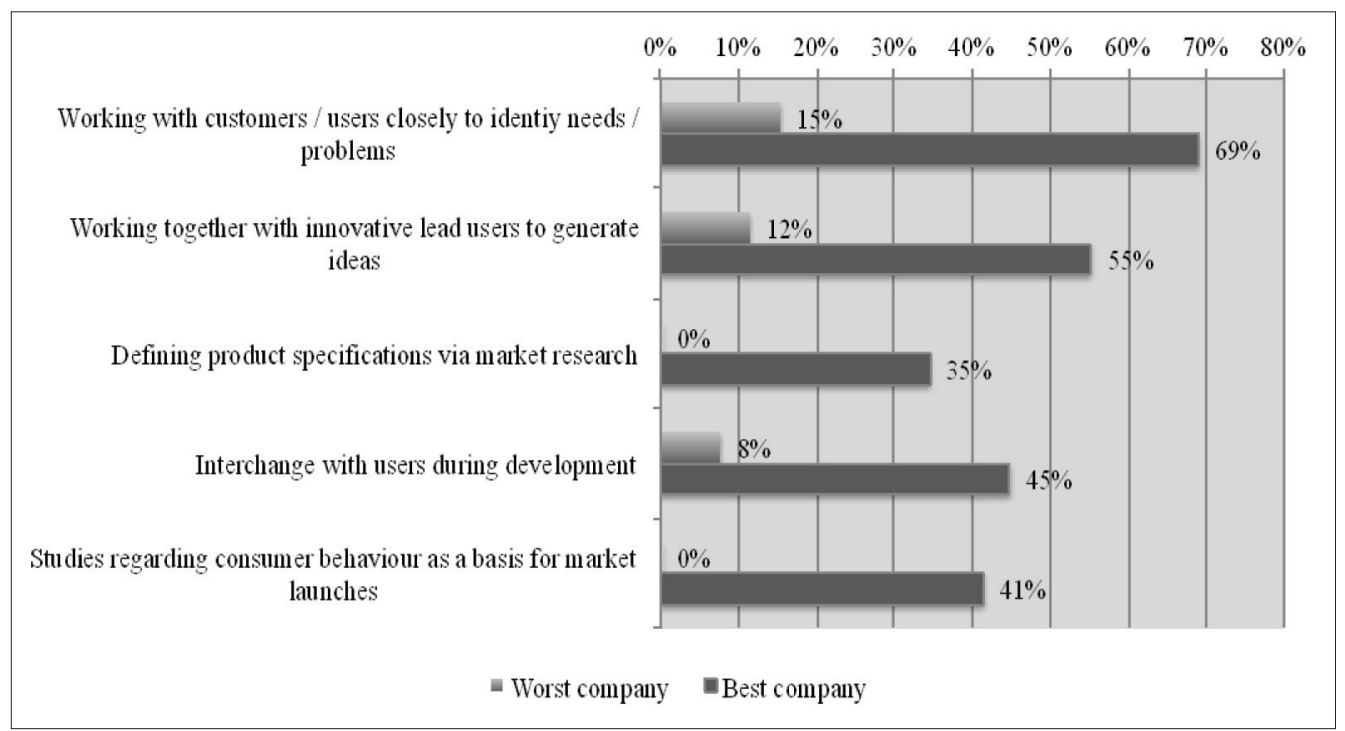

Figure 3. Proximity to customers of companies with different market performance

Source: Wentz, 2008: 112

Wentz confirms this by stating that even though it is a lot of work to search for consumer insights in detail, it is what makes innovation successful in the end. Innovation projects with regular customer input have a success probability that is twice as high and a market share that is $70 \%$ higher than projects with insufficient market input (Wentz, 2008: 111). Besides, the most successful companies in the market work together with customers much more closely to get to know their needs and problems than those companies being less successful (Wentz, 2008: 112). 0 shows the results of a study regarding the proximity to customers. It reveals that the best performing company works together with customers very closely in every aspect and phase of the innovation process.

Probably this is the biggest challenge about innovation: It is essentially about learning and an open-minded attitude (Tidd, Bessant, 2009: 101). It cannot be forced. For every innovation, there is a right time and a right place, and companies need patience on the one hand and vigilance on the other (Eberl, Puma, 2007: 102), to make value out of opportunities. It does not work by pushing a button. Ideas are generated and formed through inspiration - a little bit like music (Eberl, Puma, 2007: 237).

Another very important key characteristic of innovative organizations is their willingness to experiment and to challenge the status quo (Von Stamm, 2008: 476). It requires curiosity and openness to change (Deschamps, 2008: 9), even though this might be risky, costly and success cannot be promised in the beginning. So, apart from many external drivers that this part has explained, there still seems to be much more about a company's philosophy, strategy and state of mind to make innovation work. This brings us to the internal influences on innovation, which will be discussed in the following section.

The Boston Consulting Group annually publishes a list of the most innovative companies which shows that they come from all branches, sizes, and backgrounds (McGregor, 2007: 3). Besides, every country has a lot of very small, local companies that live on innovation, too. Therefore, you can probably not suggest the one and only organizational model for a company to be innovative. What seems to be much more important is that a company is flexible and fast in reaction to changed market needs. Most importantly, companies need to be able to learn very quickly and to manage their processes according to customers' and employees' needs (Wildemann, 2010: 12). A constantly learning organization that rewards innovation and gives free space for developing ideas and being creative must be the vision for today's companies (Wildemann, 2010: 12).

Since innovation becomes more and more a corporate-wide task, involving production, marketing, administration, purchasing and many other functions, this does provide pressure to set up more organic models 
(Tidd, Bessant, 2009: 107). Generally, a flexible organizational structure can be a successful stimulus to the development of innovation capability because it allows different work practices (Terziovski, 2007: 206).

Innovative companies are committed to their course of innovation (Von Stamm, 2008: 480) and believe in the long-term success and sustainability that will make it pay-off.

\section{"The difference between success and failure in innovation is leadership." Marc Benioff, CEO salesforce.com ${ }^{4}$ (Davila et al., 2006: 259)}

This quote alone states the important role that leadership and management play in innovative companies. Even though discovery and creative thought cannot be planned by a leader (Klemm, 2001: 452), there is scientific proof that innovation management depends on the leadership at the top. The team at the top must want it to happen and trust their people to make it happen (Davila et al., 2006: 13). As always, the way leaders behave sends strong signals to employees. The McKinsey survey from 2007 found that the top two motivators of behaviour to promote innovation are strong leaders who encourage and protect it and top executives who spend their time actively managing and driving it (Barsh et al., 2008: 39). Besides, the orientation toward innovation must come, primarily, from the highest level of management (Amabile, 1996: 8), because every innovation requires the support of a manager to survive (Davila et al., 2006: 114). There are cases enough, showing that ideas which challenge the status quo, face an uphill struggle to gain acceptance (Tidd, Bessant, 2009: 99) - sometimes just because they are new and things have never been done like this before in the organization. What is done and how it is done in an organization is strongly influenced by leaders and managers (Terziovski, 2007: 31).

Another important und controversial point in innovation is the issue of rewards and incentives. Whereas Klemm points out that workers will try to generate new ideas when they know that management rewards them (Klemm, 2001: 455), Barsh et al. clearly state that an environment where people understand that their ideas are valued, trust that it is safe to express those ideas, and oversee risks collectively, together with their managers, can be much more effective than monetary incentives in sustaining innovation (Barsh et al., 2008: 37-47).

Another important issue, in the authors' point of view, is satisfaction and emotional engagement at work. In 2010, a study for Gallup Inc. in Germany revealed that only $14 \%$ of German employees feel highly committed to their companies. $63 \%$ have a low commitment and another $23 \%$ feel they have no commitment at all to their employer (Nink, 2012: 10). The study estimates that the so-called "inner notice" of so many employees doing work-to-rule only, causes an economic damage in Germany of around 124 billion Euros per year (Nink, 2012: 11). According to the study, the emotional engagement of employees also has a very high impact on innovation power. As 0 shows, employees with a high commitment to their company bring in many more new ideas to discuss with their leader than employees who do not really feel committed. Their contribution to innovation power, in fact, is $197.8 \%$ higher than the one of employees with no emotional engagement. So, it must be in the interest of innovative companies to make their employees emotionally involved and ensure high commitment at work.

Furthermore, topics such as environmental responsibility, sustainability in company success, growing internationality even of small and mid-sized companies, and corporate social responsibility might influence a company's innovation power. In the end, it is hard to limit the innovation influencers to special, concrete aspects. They all seem to be linked to each other somehow and can hardly be prioritized.

Studies have shown that innovation is extremely complex and involves the effective management of a variety of different activities (Trott, 2008: 25). The key findings of a survey from 2006 by Business Week and Boston Consulting Group of over 1.000 senior managers in 0 reveal how different the explanations for a company to be innovative can be.

4 Salesforce.com is a cloud computing enterprise established only in 2004. It offers sales and marketing business applications for companies of any size and provides these via a server. The customers therefore only pay a monthly fee for downloads and do not need any software installations. Salesforce.com serves approximately two million users today. 


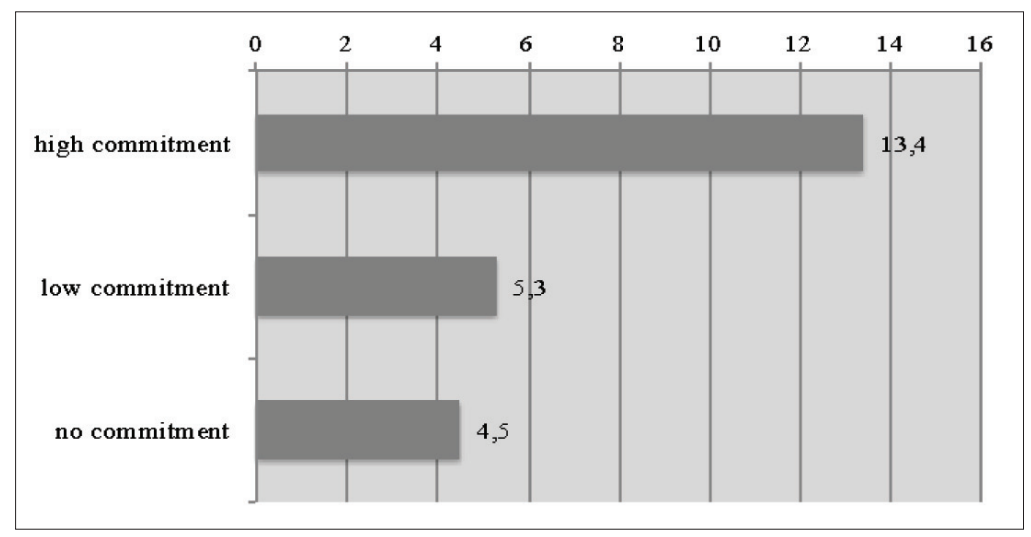

Figure 4. Number of ideas that employees explicitly brought to discussion with their leaders in the last 6 months Source: Nink, 2012: 18

Table 1. Explanation for innovative capability

\begin{tabular}{|l|l|}
\hline \multicolumn{1}{|c|}{ Innovative firm } & \multicolumn{1}{c|}{ Explanation for innovative capability } \\
\hline Apple & Innovative chief executive \\
\hline Google & Scientific freedom for employees \\
\hline Samsung & Speed of product development \\
\hline Procter \& Gamble & Utilisation of external sources of technology \\
\hline IBM & Share patents with collaborators \\
\hline BMW & Design \\
\hline Starbucks & In-depth understanding of customers and their cultures \\
\hline Toyota & Close cooperation with suppliers \\
\hline
\end{tabular}

Source: Trott, 2008: 25

Having shown this, it still does not become obvious what a company has to do to increase innovation power. However, there is scientific research showing that, in general, there are many different influencing factors. While some studies claim a certain group of factors being crucial, other studies ignore the very same factors and claim very different factors to be decisive (Van der Panne et al., 2003: 310).

To sum up, there is no general definition of success factors for innovation power that all experts would agree on. Although this makes the topic hard to grasp there is a common consent in scientific research that innovation culture is a very important factor. Company culture is undisputedly considered crucial to the firm's technological capabilities in the long term (Van der Panne et al., 2003: 312). Other authors can also reconfirm this. Von Stamm, for example, states that creating an innovative organization requires a people-centred approach; after all, it is people who come up with new ideas and transform them into innovative products or services, not processes (Von Stamm, 2008: 329). Davila explains that innovation needs to be an integral part of the way a company operates every day and of the whole business mentality (Davila et al., 2006: 11). A McKinsey Quarterly study from 2008 found that senior executives almost unanimously - 94 per cent - say that people and corporate culture are the most important drivers for innovation (Barsh et al., 2008: 38). After all, a culture of innovation is the fertile ground in which tomorrow's innovations will bear rich fruit and make the company grow sustainably in the end (Eberl \& Puma, 2007: 6). Thus, the capability of an organization to create value out of innovation heavily depends on a strong innovation culture (Terziovski, 2007: 213). Von Stamm reconfirms that creating the right culture is key to innovation (Von Stamm, 2008: 475). The literature on organizational innovation, both anecdotal and empirical, emphasizes the importance of culture as a major determinant (Prajogo, Ahmed, 2006: 501). 


\section{Innovation determinants in Germany}

In Germany, innovation has a very long history. It is a land of ideas where education, science and research play a central role (German Center for Research and Innovation, 2012). In addition to that, research and innovation are among the German government's highest priorities, and there are a variety of public and private institutions conducting research (German Center for Research and Innovation, 2012). The Max-Planck-Gesellschaft or the Fraunhofer Institute for example gain acceptance worldwide. Moreover, the industry plays a very important role in the German research landscape. More than two-thirds of annual funding invested in research in Germany comes from the private sector and these funds are spent on the companies' own research as well as on joint projects with partners from science (German Center for Research and Innovation, 2012). In German companies, engineering excellence is still the best way to get ahead in a career (Knowledge @ Wharton, 2009: 2). Maybe that is why, historically, the high standard of technical expertise is the most important driver of German innovation. Germany actually registers more patents per capita than any other nation (Knowledge@Wharton, 2009: 1).

However, a survey for the Centre for European Economic Research in 2005 found out that there is no clear overall trend in innovation. Even though the expenditure on innovation rose strongly, by $2 \%$, the proportion of all firms that implemented innovations did not increase (Aschhoff et al., 2006: 2). Besides, the share of revenue from new products also remained constant on average across all sectors. Germany has a very high level of innovation though: In 2004, $60 \%$ of manufacturing firms successfully brought new products to the market or introduced new processes (Aschhoff et al., 2006: 2).

Prof. Dr. Annette Schavan, member of the German Bundestag and Federal Minister of Education and Research announced in 2009 that further investments in education, science and research are necessary to make a commitment to a path of growth and economic success after the crisis for Germany (Federal Ministry of Education and Research, 2009: foreword). A report for the very same Ministry claims that the financial and economic crisis of 2009 will not stop the global race for knowledge from re-accelerating. International competition for talent, technology superiority and market leadership will continue to grow. In countries relatively poor in natural resources, such as Germany, enhanced innovation will provide the decisive basis for growth, new jobs and prosperity (Federal Ministry of Education and Research, 2009: 4). Therefore, innovation was the key to a rapid recovery in Germany and both, politics and industries, understood that at the time. Porter and Stern reconfirm this in their report on global competitiveness. Especially advanced nations, with relatively high labour costs and equal access to global markets, such as Germany, will not sustain competitive if they produce standard products and use standard methods only. Instead, advantage must come from the ability to create and then commercialize new products and processes (Porter \& Stern, 2001b: 2). Thus, innovation in Germany, is not only historically natural - today, it is much more a necessity to survive! Furthermore, Porter and Stern state that competitiveness advances when the public and private sectors together promote a favorable environment for innovation (Porter, Stern, 2001b: 2). Germany ranks 3rd in Porter's and Stern's overall innovative capacity index (Latvia: 41 st) with rank 7 regarding the innovation policy subindex (Latvia: rank 51) (Porter, Stern, 2001b: 4). The report firstly indicates that there are very different preconditions depending on geographic locations. The findings reveal the striking degree to which the national environment matters for success in innovative activity, indeed. Actually, building innovative capacity has a strong relationship to a country's overall competitiveness and level of prosperity and it must be seen as one of the biggest challenges for many countries in Latin America, Southern and Eastern Europe for the years to come (Porter, Stern, 2001b: 15).

In another article about the topic, the authors state that even though the United States and Switzerland maintain the top positions regarding innovative capacity of the OECD countries, other nations such as Japan and Germany have invested heavily in the conditions underpinning national innovative capacity and improved their relative standing as innovators (Porter, Stern, 2001a: 32). So, regardless the already impressive innovation performance Germany has, it is known for improvement. On the global innovation index 2011, Germany ranked $12^{\text {th }}$ (Dutta, 2011: xviii). Considering that very small countries, such as Iceland for exam- 
ple, overtake Germany here it goes without saying that there actually is room for improvement in Germany. However, a score of 88 out of 100 indicates that the political environment is very innovation friendly (Dutta, 2011b: 103).

\section{Innovation determinants in Latvia}

The Ministry of Economics of the Republic of Latvia worked out and Latvia investment and development agency managed a wide range of EU structural funds co-financing innovation support programs. In the context of such programs firms would have a chance to receive financial support on all stages of innovation development, namely, from idea to new product and theology creation and implementation in the production processes (Ministry of Economics of Republic of Latvia, 2011). Innovation support activities carried out through popularization of the concept of innovation among young and experienced entrepreneurs, through education and motivation to start innovative entrepreneurship. The Ministry of Economics of the Republic of Latvia announced that support activities are devoted to the private sector and science sector in order to promote collaboration activities between the academic society and industry representatives in the context of joint project implementation. In addition to this, the Ministry of Economics of the Republic of Latvia argues that support activities are also devoted to creation of new technologies and products, and its implementation into production processes.

Support activities are devoted to huge projects of production facility creation with the purpose to simulate local entrepreneurs to invest in science and technology projects as well as to attract foreign investments to the high added value sector. Plenty of activities were undertaken in order to provide entrepreneurs with access to finance for the implementation of innovative projects. On the parallel basis the Ministry of Economics in cooperation with the Latvia investment and development agency develop new support tools for innovation promotion in Latvia. The Ministry of Economics of the Republic of Latvia summarises main innovation support programs within which projects are being implemented: Technology transformation contact points; competence centres - promotion of joint scientists; business incubators; creation of new products and technologies; creation of new products and technologies; high added value investments. Never the less, according to the latest Eurostat data the lowest hare of innovative enterprises, meaning enterprises with innovation activity (product, process, ongoing or abandoned, organisational and marketing innovation),was recorded in Latvia (Eurostat, 2012: 74). According to the latest data provided by Central Statistical Bureau it must be admitted that the number of innovatively active enterprises in industry in total in Latvia increased since the period of 2004-2006 from 379 (or 14.6\% of all enterprises in Latvia) enterprises to 707 (26.9\% of all enterprises in Latvia) innovative enterprises in the time period of 2006-2008 (Tab. 2).

Table 2. Number of innovative enterprises by kind of activity

\begin{tabular}{|c|c|c|c|c|}
\hline & \multicolumn{2}{|c|}{ Innovatively active enterprises } & \multicolumn{2}{|c|}{$\begin{array}{c}\text { Innovatively active enterprises as per cent of the } \\
\text { total number of enterprises }\end{array}$} \\
\hline & 2004-2006 & 2006-2008 & 2004-2006 & 2006-2008 \\
\hline \multicolumn{5}{|c|}{ Industry - total } \\
\hline Total & 379 & 707 & 14.6 & 26.9 \\
\hline $10-49$ & 184 & 457 & 9.8 & 23.5 \\
\hline $50-249$ & 155 & 201 & 24.3 & 33.4 \\
\hline$>250$ & 40 & 49 & 44.0 & 64.5 \\
\hline \multicolumn{5}{|c|}{...manufacturing } \\
\hline Total & 366 & 658 & 15.0 & 28.1 \\
\hline $10-49$ & 180 & 427 & 10.3 & 24.4 \\
\hline $50-249$ & 152 & 189 & 25.4 & 35.7 \\
\hline$>250$ & 34 & 42 & 41.0 & 66.7 \\
\hline
\end{tabular}

Source: Central Statistical Bureau of Latvia, Innovation data, accessed on 01.05.2012 
The highest share of innovative enterprises was depicted especially in small enterprises with the number of employees from 10 to 49: 184 (or 9.8 \% of all enterprises in Latvia) innovative enterprises in time period of 2004-2006 and 457 (or 23.5\% of all enterprises in Latvia) in 2006-2008 respectively. The lowest share of innovative enterprises was depicted especially in large enterprises with the number of employees from 250: 40 (or $44.0 \%$ of all enterprises in Latvia) innovative enterprises in time period of 2004-2006 and 49 (or $64.5 \%$ of all enterprises in Latvia) in 2006-2008 respectively. However, it must be admitted that there were few large enterprises in Latvia at all in the industry in total. The number of innovatively active enterprises in manufacturing in total in Latvia increased since the period of 2004-2006 from 366 (or $15.0 \%$ of all enterprises in Latvia) enterprises to 658 (28.1\% of all enterprises in Latvia) innovative enterprises in the time period of 2006-2008. As well as in the industry, the highest share of innovative enterprises in manufacturing was depicted especially in small enterprises with the number of employees from 10 till 49: 180 (or 10.3\% of all enterprises in Latvia) innovative enterprises in time period of 2004-2006 and 427 (or $24.4 \%$ of all enterprises in Latvia) in 2006-2008 respectively. The lowest share of innovative enterprises was depicted especially in large enterprises with the number of employees from 250: 34 (or $44.1 \%$ of all enterprises in Latvia) innovative enterprises in time period of 2004-2006 and 42 (or $66.7 \%$ of all enterprises in Latvia) in 2006-2008 respectively. Actually, there were few large enterprises in Latvia at all in manufacture in total.

Latvian experts from the high education sector, entrepreneurship sector, economics and finance sector, research institutions, governmental and non-governmental sector as well as policy makers took part in an expert discussion on "Education. Innovation. Entrepreneurship". In the context of the expert discussion there were announced key issues related with innovation, education and state competitiveness. The experts admitted that there is no actual innovation state policy in Latvia.

The experts admitted that there is a lack of understanding about the creation capabilities of effective innovation system. These facts have a high negative impact on education sector, science and entrepreneurship activities. Respectively, coherent and targeted efforts are missing in the context of achieving sustainable public welfare and stable economy development. There are no specific institutions in Latvia which main responsibility area relies on innovation policy creation as well as effective innovation system creation and development.

Also there is scarce cooperation between enterprises and the academic society, which results in a delay of innovation creation. There is a lack not only of information but also of interest about a probable cooperation with researchers in the sphere of innovation. However, plenty of documents are created in order to force Latvian innovation policy but, in fact, the realization of the plan goes on quite slowly (Dubra, 2011: 101).

According to the latest innovation related data provided by the Central Statistical Bureau of Latvia (see tab. 3) it must be announced that there was depicted a positive trend in expenditure on research and development by business enterprise sector. Namely, business enterprise sector expenditure on research and development increased from 24.9 million till 28.5 million during the period of 2008-2010. Expenditure on research and development by higher education sector decreased from 47.2 million till 30.8 million during the period of 2008-2010. Gross domestic expenditure on R\&D decreased from 99.5 million till 77.0 million during the period of 2008-2010. As a positive trend, it should be announced that total enterprise funding for research and development increased a little bit and reached 29.9 million in 2010. It is a pity to announce that the total state funding for research and development decreased dramatically from 47.1 million till 20.3 during the period of 2008-2010.

The R\&D expenditure as per cent of GDP slightly decreased from $0.62 \%$ till $0.60 \%$ during the period of 2008-2010. Although the business enterprises' funds in the government sector as expenditure on research and development increased from 2.7 million to 4.0 million, nevertheless, whole the government sector expenditure on research and development decreased from 27.4 million to 17.7 million during the period of 2008-2010. Public funding for science and research run behind other developed countries of the European Union. There is a poor and insufficient state financing of scientific-research institutions that result in poor invention commercialization, lack of motivation to build an adequate infrastructure for technological innovation creation and difficulties in attraction of EU funds in the context of project developments. 
Table 3. Expenditure on research and development by sector and its financing (mln LVL)

\begin{tabular}{|c|c|c|c|}
\hline & 2008 & 2009 & 2010 \\
\hline BUSINESS ENTERPRISE SECTOR & 24.9 & 21.8 & 28.5 \\
\hline Business enterprises' funds in business enterprise sector & 20.4 & 18.2 & 23.5 \\
\hline Government funds in business enterprise sector & 0.8 & 0.8 & 1.0 \\
\hline Foreign funds in business enterprise sector & 3.7 & 2.8 & 4.0 \\
\hline GOVERNMENT SECTOR & 27.4 & 14.8 & 17.7 \\
\hline Business enterprises ${ }^{6}$ funds in government sector & 2.7 & 3.2 & 4.0 \\
\hline Government funds in government sector & 15.9 & 8.5 & 6.4 \\
\hline Foreign funds in government sector & 8.8 & 3.1 & 7.3 \\
\hline HIGHER EDUCATION SECTOR & 47.2 & 23.3 & 30.8 \\
\hline Business enterprises' funds in higher education sector & 3.8 & 0.7 & 2.4 \\
\hline Subtotal government funds in higher education sector & 30.4 & 17.5 & 12.9 \\
\hline Funding of higher education & 2.5 & 1.8 & 1.1 \\
\hline Foreign funds in higher education funds & 10.5 & 3.3 & 14.4 \\
\hline GROSS DOMESTIC EXPENDITURE ON R\&D (GERD) & 99.5 & 59.9 & 77.0 \\
\hline Total enterprise funding for research and development & 26.9 & 22.1 & 29.9 \\
\hline Total state funding for research and development & 47.1 & 26.8 & 20.3 \\
\hline Total higher education funding for research and development & 2.5 & 1.8 & 1.1 \\
\hline Total funding for research and development by foreign countries & 23.0 & 9.2 & 25.7 \\
\hline R\&D EXPENDITURE AS PER CENT OF GDP & 0.62 & 0.46 & 0.60 \\
\hline
\end{tabular}

Source: Central Statistical Bureau of Latvia, Innovation data, accessed on 01.05.2012

\section{Conclusions}

Firstly, and as a key theoretical aspect of the concept on innovation this paper reveals that innovation is a fundamental element of long-term success. It matters not only at the level of the individual enterprise but also at industry level and finally at the national economic level.

Secondly, this paper provides different findings of factors that have a high impact on innovation. Customers, $R \& D$ department, employees, competitors, business partners, external developers and even new governmental, environmental regulations inspire enterprises to be more innovative. Another key prerequisite of innovation relies on enterprise willingness to experiment and to adopt itself to the modern challenging environment. Leadership intensity, innovation oriented organization culture, management style as well as rewards and incentives lead to the increase of enterprise innovation power through employee's satisfaction and emotional engagement at work. Environmental responsibility, sustainability in company success, growing internationality even of small and mid-sized companies, and corporate social responsibility might influence a company's innovation power.

Then, as a third point of this paper, the situation about innovation determinants in Germany is highlighted. Of course, Germany does have a high level of innovation already, but, taking into account the innovation activities of India and China for example, the challenge to continuously innovate will not become any easier in the years to come. Therefore, it must be stated as a conclusion that there is room for improvement in Germany as well. However, the German situation can be valuable for broadening the innovation theory and improving innovation-related practices in Latvia.

Innovation activities of Latvian enterprises are not on a satisfactory level, as the fourth part of this paper reveals when examining the innovation determinants for Latvia. Never the less, plenty of documents were worked out in order to force the Latvian innovation policy but in fact, and the realization of the plan goes on quite slowly. It must be admitted that an R\&D expenditure rate of $0,60 \%$ of the GDP is still below the Lisboan strategy of $3 \%$. There is a specific need to ensure the growth of Latvia's national economy through the creation of added value products/services and increase of work efficiency throughout the whole innovation process promotion. Therefore, gaining insights on factors that have supported or unfortunately have not 
supported enterprises' innovation activities in transition economies of Central Europe like Germany can be an inspiration.

Finally and to sum up, for both countries the authors state that innovation is most important to survive and grow sustainably. Further research should explore other modes of analysis of influential factors on innovation creation that reflects on the enterprise capacity to achieve competitive advantage. Also it is needed to extend the methodology of evaluation of influential factors on the creation of innovation. Research in other industries will probably contribute to validation of the relationships explored in this research.

\section{References}

Amabile, T. M. (1996). Creativity and innovation in organizations. Harvard Business School, January 5t (9-396-239), p. 1-15.

Aschhoff, B. et al. (2006). Results of the German innovation survey 2005. Mannheim. Available at: www.zew.de.

Barsh, J., Capozzi, M. M., Davidson, J. (2008). Leadership and innovation. McKinsey Quarterly, Vol. 1, p. 37-47.

Central Statistical Bureau of Latvia, Innovation data. Available from: http://www.csb.gov.lv/statistikas-temas/inovacijas-galvenie-raditaji-30336.html [Accessed 1st May 2012].

Davila, T., Epstein, M. J., Shelton, R. (2006). Making innovation work. New Jersey: Wharton School PublishingDeschamps.

J. P. (2008). Innovation leaders: How senior executives stimulate, steer, and sustain innovation. West Sussex: John Wiley \& Sons Ltd.

Dubra, I. (2011). Mobilization of human capital in science and technology for innovation creation. Scientific papers University of Latvia, Vol. 771, p. 100-113.

Dutta, S. (2011). The Global Innovation Index 2011. Fontainebleau.

Eberl, U., Puma, J. (2007). Innovative minds - A look into Siemens'idea machine. Erlangen: Publics Corporate Publishing.

Engeser, M. (2010). Aufbrechen, bevor das Denken zementiert. Wirtschaftswoche, Vol. 47, p. 96-100.

Eurostat Pocketbooks, Science, technology and innovation in Europe. (2012). European Commission. Luxembourg: Office for Official Publications of the European Communities.

Federal Ministry of Education and Research. (2009). Research and Innovation for Germany. Berlin. Available at: http:// www.bmbf.de.

German Center for Research and Innovation. (2012). Resources for graduates and doctoral students. http://www.germaninnovation.org. Available at: http://www.germaninnovation.org [Accessed April 23, 1BC].

Kerka, F., Kriegesmann, B. (2010). Big Ideas erkennen und Flops vermeiden - Wie Sie die Innovationsperformance Ihres Unternehmens erhöhen. Institut für angewandte Innovationsforschung e.V.

Klemm, W. R. (2001). Leadership: Creativity and Innovation. In: R. I. Lester, A. G. Morton (eds.). Concepts of Air Force Leadership. Alabama: Air University Press, p. 449-461.

Knowledge @ Wharton. (2009). Innovation thrives among german firms, though hurdles persist. http://knowledge. wharton.upenn.edu/article.cfm?articleid=2199, p. 1-4. Available at: http://knowledge. wharton.upenn.edu/article. cfm?articleid=2199.

Langenscheidt. (2001). Großes Schulwörterbuch Lateinisch-Deutsch. Berlin \& München: Langenscheidt Verlag.

Ministry of Economics of Republic of Latvia, Innovation Support Activities, EU Structural Funds for Innovation. (2011). Available at: http://www.em.gov.lv/em/2nd/?lng=lv\&cat=30281[Accessed 1st May 2012].

McGregor, J. (2007). This way to innovation. Business Week \& Boston Consulting Group, p. 4-9.

Nink, M. (2012). Engagement Index Deutschland 2011. Berlin.

Porter, M. E., Stern, S. (2001a). Innovation: Location matters. MIT Sloan Management Review, Vol. 42(4), p. 28-36.

Porter, M. E., Stern, S. (2001b). National Innovative Capacity. Available at: http://www.isc.hbs.edu/Innov_9211.pdf.

Prajogo, D. I., Ahmed, P. K. (2006). Relationships between innovation stimulus, innovation capacity, and innovation performance. R\&D Management, Vol. 36/5, p. 499-516.

Scarbrough, H. (2003). Knowledge management, HRM and the innovation process. International Journal of Manpower, Vol. 24(5), p. 501-516.

Statistics Canada. (2006). Labour Force Survey. Ottawa.

Terziovski, M. (2007). Building innovation capability in organizations. London: Imperial College Press.

Tidd, J., Bessant, J. (2009). Managing innovation. 4th editio. West Sussex: John Wiley \& Sons Ltd.

Trott, P. (2008). Innovation management and new product development. 4th editio. Essex: Pearson Education Limited.

Van der Panne, G., Van Beers, C., Kleinknecht, A. (2003). Success and failure of innovation: a literarure review. International Journal of Innovation Management, Vol. 7(3), p. 309-338. 
Von Stamm, B. (2008). Managing innovation, design, and creativity. 2nd editio. West Sussex: John Wiley \& Sons Ltd. Wentz, R. C. (2008). Die Innovationsmaschine - Wie die weltbesten Unternehmen Innovationen managen. Berlin \& Heidelberg: Springer Verlag.

Wildemann, H. (2010). Unternehmen müssen schneller lernen. Frankfurter Allgemeine Zeitung GmbH, p. 12.

\section{SVARBÜS INOVACIJOS VEIKSNIAI：LATVIJOS IR VOKIETIJOS ATVEJŲ ANALIZE}

Carolin Kuhn, IlonaDubra, Erika Sumilo

Latvijos universitetas (Latvija)

\section{Santrauka}

Straipsnyje aptariami veiksniai, darantys ittaką organizacijų inovacinei veiklai. Straipsnio tikslas - nustatyti svarbius inovacinę veiklą lemiančius veiksnius Vokietijoje ir Latvijoje. Pateikiama lyginamoji inovacinès galios Vokietijoje ir Latvijoje analizè. Pirmoje straipsnio dalyje nagrinèjami teoriniai inovacijos koncepcijos aspektai. Antroje dalyje atskleidžiama svarbių inovacijos veiksnių gamybos organizacijose esmè. Trečioje ir ketvirtoje dalyse pateikiama empirinė Latvijos ir Vokietijos atvejų analizè. Palyginę naujausius abiejų šalių statistinius duomenis autoriai padare išvadą, kad inovacinè veikla Latvijos organizacijose yra nepakankamo lygio. Teigiama, kad Latvijoje nèra tinkamos inovacinès veiklos politikos. Tuo tarpu Vokietijoje inovacinè veikla buvo viena esminių priežasčių, lèmusių greitą Vokietijos ekonomikos atsigavimą po ekonominès krizès, valstybè ir verslas bendradarbiavo siekdami šio tikslo. Inovacija Vokietijoje turi istorini pagrinda, Vokietija nemažai investavo siekdama sudaryti sąlygas, kurios nulèmé šalies inovacinius pajègumus, ir taip sustiprino savo, kaip inovatoriaus, reputaciją. Todèl Latvijai, tokiai pat Europos Sajungos nariai kaip ir Vokietija, ypač svarbu pasinaudoti sèkminga Vokietijos patirtimi inovacijų srityje.

PAGRINDINIAI ŽODŽIAI: inovacija, augimas, Vokietija, Latvija, konkurencingumas, organizacija.

JEL KLASIFIKACIJA: A11; A12; A13; H52; M21; O16; O31; O32; O34; O38; O52 